\title{
Zika infection in pregnancy is linked to range of fetal abnormalities, data indicate
}

\author{
Susan Mayor
}

London

Infection with Zika virus in pregnancy is associated with a range of fetal abnormalities, including fetal death and growth restriction in addition to neonatal microcephaly, shows a preliminary report on data from Brazil, ${ }^{1}$ announced at a World Health Organization report last week. ${ }^{2}$

Researchers tested blood and urine specimens in pregnant women who had developed a rash in the previous five days and who were cared for at centres in Rio de Janeiro. The researchers tested for Zika virus before following the women prospectively, collecting clinical and ultrasound scan data.

A total of 88 women were enrolled in the study from September 2015 to February 2016. More than three quarters (72 of 88) of them tested positive for Zika virus in blood, urine, or both. The timing of infection ranged from five to 38 weeks of gestation.

Fetal abnormalities were detected in 12 of 42 women testing positive for Zika virus who underwent Doppler ultrasonography (29\%) but in none of the 16 women who tested negative.

Death of the fetus occurred in two of the women infected with Zika, at 36 and 38 weeks of gestation. Other adverse events included in utero growth restriction with or without microcephaly (five fetuses) and ventricular calcifications or other central nervous system lesions (seven fetuses). Abnormal amniotic fluid content or cerebral, umbilical, or placental artery abnormalities were seen in seven fetuses.

So far eight of the 42 women with Zika infection who underwent ultrasonography in pregnancy have delivered their babies, and the researchers said that the ultrasonographic findings were confirmed.

For The BMSs latest articles on the Zika virus epidemic go to bmj.co/ zika.

1 Brasil P, Pereira JP Jr, , Raja Gabaglia C, et al. Zika virus infection in pregnant women in Rio de Janeiro: preliminary report. N Engl J Med 2016;4. doi:10.1056/ NEJMoa1602412. .26943629.

2 Gulland A. Zika virus may be linked to several birth defects, expert warns. BMJ 2016;352:11322.26940642.

Published by the BMJ Publishing Group Limited. For permission to use (where not already granted under a licence) please go to http://group.bmj.com/group/rights-licensing/ permissions 